\title{
Characteristics of Concentration and Composition of Heavy Metals in Seawater, Sediment and Macroalgae, Ulva sp., in Yatsu Tidal Flat in Tokyo Bay, Japan
}

\author{
HIDEKI TATSUMOTO', YUICHI ISHII ${ }^{2}$, MOTOI MACHIDA ${ }^{1}$, MASAMI AIKAWA $^{3}$, \\ YOKO FUJIMURA ${ }^{4}$, TOHRU YABE ${ }^{5}$, and KAZUO TAKI ${ }^{6}$ \\ ${ }^{1}$ Faculty of Engineering, Chiba University \\ ${ }^{2}$ Graduate School of Science and Technology, Chiba University \\ / 1-33, Yayoicho, Inage, Chiba, 263-8522, Japan. \\ ${ }^{3}$ Faculty of Science, Kisarazu National College of Technology \\ / 2-11-1, Kiyomidai-higashi, Kisarazu, Chiba 292-0041, Japan \\ ${ }^{4}$ Chiba Prefectural Environmental Research Center / 3-5-1, Inagekaigan, Mihama, Chiba 261-0005, Japan \\ ${ }^{5}$ National Institute for Environmental Studies / 16-2, Onogawa, Tsukuba, Ibaraki, 305-8506, Japan \\ ${ }^{6}$ Faculty of Engineering, Chiba institute of Technology \\ / 2-17-1, Tsudanuma, Narashino, Chiba, 275-0016, Japan
}

\begin{abstract}
Macroalgae, Ulva sp., seawater and sediments in Yatsu tidal flat, Japan were examined to clarify the characteristic distributions of heavy metals and their interactions within these compartments of the ecosystem. The heavy metal concentrations were higher in fall than summer for $\mathrm{Fe}, \mathrm{Cu}$ and $\mathrm{Zn}$, but were constant with respect to season for $\mathrm{Pb}$ and $\mathrm{Cd}$. The distribution of heavy metals in Ulva sp. harvested from Yatsu tidal flat was close to in Ulva sp. grown in other parts of the world with the following decreasing order of concentration of $\mathrm{Fe} \gg \mathrm{Zn}>\mathrm{Cu} \geq \mathrm{Pb} \gg \mathrm{Cd}$, but differed from that of other. Ulva spp. was considered to have an inherent characteristic ratio of heavy metals. In the sediments, heavy metal content was higher in the muddy area of the tidal flat than sandy area, while the compositions were similar for the two areas. The difference in heavy metal content would be attributed to the difference in organic matter and sediment particle size. The major heavy metal in the suspended particulate matter (SPM) in seawater was determined to be Fe followed by $\mathrm{Zn}, \mathrm{Pb}, \mathrm{Cu}$ and $\mathrm{Cd}$, which exhibited a similar composition as those in the sediments. SPM was considered to be derived by tidal shear forces. Absorption of heavy metals into Ulva sp. did not depend on the seawater concentrations, but on the absorbability inherent in Ulva sp. In comparisons of Concentration Factors for heavy metals in Ulva sp., essential elements as $\mathrm{Fe}, \mathrm{Cu}$ and $\mathrm{Zn}$ were preferentially absorbed compared to nonessential metals as $\mathbf{P b}$ or $\mathbf{C d}$.
\end{abstract}

Key words: bioaccumulation, Concentration Factor, inherent composition, selective absorption, Ulva sp.

\section{INTRODUCTION}

Due to their toxicity, heavy metals are important for evaluating the pollution of marine environments. Numerous studies on heavy metal contamination in macroalgae have been carried out in recent years ${ }^{1,2)}$. It has been reported that macroalgae could be 
an indicator of the degree of heavy metal contamination in costal areas since the macroalgae exhibit a large capability for accumulating heavy metals ${ }^{3,4}$. Heavy metal contamination in urban areas is principally caused by human activities such as industrialization, urbanization and mining.

Heavy metals absorbed in organisms are biologically concentrated in higher animals or plants through the food chain.

The contamination of heavy metals in macroalga in Tokyo Bay has not been examined, though large amounts of green macroalga Ulva sp. were observed recently in the costal areas of Tokyo Bay, which is surrounded by the Tokyo and Yokohama metropolitan areas. Several tidal flats in the area have been artificially developed. One of these, the Yatsu tidal flat located in an innermost area in Tokyo Bay has an area of 40 ha and was used as one of the tidal flats in this study. Excess growth of Ulva sp. was observed at Yatsu tidal flat, as well as the other tidal flat or shallow sea areas in Tokyo Bay. In 1993, the Yatsu tidal flat was registered by the International Union for Conservation of Nature and Natural Resources (IUCN) under the "Convention on Wetlands (Ramsar, Iran, 1971)" with the purpose of preserving migratory areas since it is used as a feeding grounds and resting area by many migrant species. Yatsu tidal flat is valuable not only for wildlife, but also for residents of cities, as a remnant of nature in an urban area. When Ulva sp., which is a primary producer in the tidal flat ecosystem, becomes polluted by heavy metals, detrimental effects on higher-level predators can be anticipated.

In this study, the concentrations and relative composition of heavy metals $\mathrm{Fe}, \mathrm{Pb}$, $\mathrm{Cu}, \mathrm{Zn}$ and $\mathrm{Cd}$ in Ulva sp. harvested from the Yatsu tidal flat were observed to clarify the influence of heavy metals on the tidal flat ecosystem. The characteristics of heavy metal content in macroalgae were compared with values found in the literature. The relationship among heavy metal contents of seawater, sediments and Ulva sp. were also discussed.

\section{SITE DESCRIPTION}

Yatsu tidal flat shown in Fig.1 is located in the Tokyo Inner Bay, Japan, at $35^{\circ} 40^{\prime} \mathrm{N}$ and $140^{\circ} 0^{\prime} \mathrm{E}$. The tidal flat was once part of an extensive foreshore-type tidal flat on the coastline of Tokyo Bay. In 1971, it was modified to an artificial lagoon-type tidal flat surrounded by a concrete wall as part of the reclamation works for industrial and residential lands, and as a result, the flow of seawater between the tidal flat and Tokyo Bay became restricted, with exchange being possible only through the Yatsu and Takase channels. Yatsu tidal flat was separated in two parts, main part and south-west part by the freeway construction. Those two parts were connected by four water conduits setting under the freeway. Inflow loads of domestic wastewater to the tidal flat were gradually decreased every year by the development of sewage disposal systems. The tidal flat had become eutrophicated by large amounts of wastewater flowing in from the drainage basin, but has improved recently. The salinity of the tidal flat water also gradually increased to the same levels as the seawater as inflows of domestic fresh water containing abundant organic matter was reduced. The sandy area consisting of sand and larger particles increased and the mud area consisting of small particles decreased in the tidal flat; the amounts of earth and sand, as well as organic materials supplied from the surrounding land area, were decreased by changing the sewage line, resulting in breaking the dynamic balance of the particles in the sediment of the tidal flat by flowing out the small particles to Tokyo $\mathrm{Bay}^{5)}$. The expansion of the sandy area is a transition in the environmental conditions that permits the growth of Ulva sp. (Chlorophta) in tidal flats. The Yatsu tidal flat became suitable for the growth of macroalga Ulva sp. when the sandy sediment area sank below the level of the seawater. As most of Yatsu tidal flat was a horizontal flat, the sediment was shown up leaving gut area at ebb tide and sunk down completely under the level of seawater at high tide. The sediment conditions were not uniform over the tidal flat; sand and sand-mud layers are 

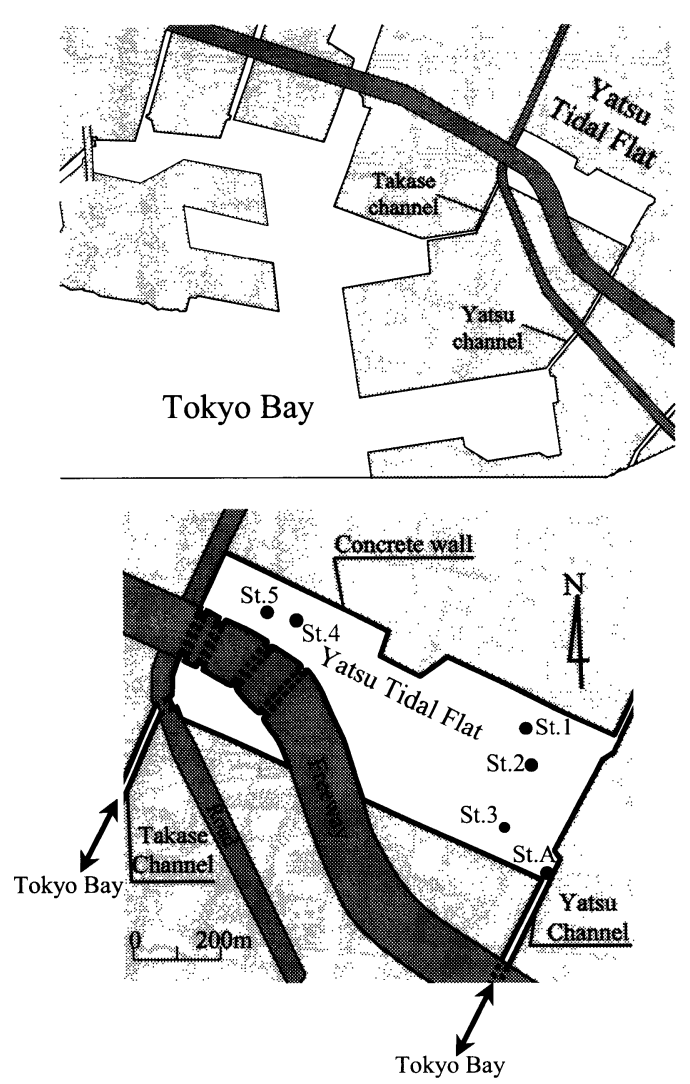

Fig. 1 Geographical features of Yatsu tidal flat and sampling points

dominant in the east region while the mud layer is dominant in the west region. Ulva sp. was observed in whole area in the sand and sand-mud areas, but not in the mud area. Ulva sp. grew, withered and piled up within the tidal flat, as they could not move out to Tokyo Bay due to the isolation of the tidal flat. The enclosed condition of the tidal flat has led to severe, detrimental effects on the ecosystem in the tidal flat; for instance, macrobenthos, which are the main food source for migratory birds were suffocated by the piles of Ulva sp.".

\section{MATERIALS AND METHODS}

\section{Field sampling}

Macroalgae Macroalga Ulva sp. samples were collected at Sts. 1 through 3 located in the east area of the Yatsu tidal flat in July and October 2002 (Fig. 1). Collected samples were rinsed with on-site seawater to remove particulate matter and benthic organisms adhering to the surface of the algae. The samples were placed in vinyl bags and transported to the laboratory.

Seawater Assuming that heavy metal concentrations in seawater do not exhibit seasonal variation, seawater was sampled 6 times from March to May 2003 at St. A of a connecting point of Yatsu tidal flat and Yatsu channel (Fig. 1). The surface water was collected using a water sampler. The seawater samples were poured into polystyrene bottles and transported to the laboratory.

Sediment Sediment samples were collected at 5 locations of Sts. 1 through 5 in October 2002. A difference in heavy metals content between Sts. 1 through 3 where macroalgae were observed and Sts. 4 and 5 where macroalgae were absent were expected because the sediment properties at Sts. 1 through 5, and particularly Sts. 1 through 3 in the Ulva sp. area, might be influenced by the withered and piled macroalga on October. Surface sediments within a $2 \mathrm{~cm}$ depth were collected using a shovel and ruler. The sediment samples were put into plastic containers after removing debris such as macrobenthos and shells and transported to the laboratory.

\section{Sample pretreatment and analysis of heavy metals content}

Macroalgae The collected macroalgae were rinsed with tap water and dried in ambient conditions for 48 hours followed by drying in an oven at $110{ }^{\circ} \mathrm{C}$ for 24 hours until a constant weight was attained. Dried samples of $6 \mathrm{~g}$ each were digested in a mixture of concentrated nitric acid and concentrated hydrochloric acid on a hot plate. The digested solution was diluted by deionized water and the concentrations of $\mathrm{Fe}$, $\mathrm{Pb}, \mathrm{Cu}, \mathrm{Zn}$ and $\mathrm{Cd}$ were determined on an Atomic Absorption Spectrophotometer (AAS; HITACHI Atomic Absorption Spectrophotometer 180-30).

Seawater Heavy metal concentrations were determined on filtered and unfiltered 
seawater. Filtered seawater was obtained by passing seawater through membrane filters (pore size $0.45 \mu \mathrm{m}$; ADOVANTEC). Nitric acid (5 vol\%) was added to both types of samples and boiled to digest the organic substances in the sample. For Fe analysis, ammonium acetate, hydroxylammonium chloride and ammonia solutions were added to the seawater sample to precipitate the Fe. The precipitate was redissolved in $50 \% \mathrm{HCl}$ solution after filter separation. The concentration of $\mathrm{Fe}$ was determined by Spectrophotometer (SHIMADZU DoubleBeam Spectrophotometer UV-210A) using 1, 10-phenanthroline hydrochloride as a coloring reagent. For analysis of $\mathrm{Cu}, \mathrm{Pb}, \mathrm{Zn}$ and $\mathrm{Cd}, 1 \% \mathrm{~N}, \mathrm{~N}$-diethyldithiocarbamate trihydrate (DDTC) was added to the seawater sample to form a metal complex with DDTC followed by extraction with butyl acetate twice. The organic solvent was evaporated by heating the extract on a hotplate. The trace organic substances remained in the flask were digested in a mixture of concentrated nitric acid and concentrated hydrochloric acid by heating on a hotplate. The remaining heavy metals were diluted with aqueous 0.1 $\mathrm{N} \mathrm{HNO}_{3}$. Concentrations of $\mathrm{Pb}, \mathrm{Cu}, \mathrm{Zn}$ and $\mathrm{Cd}$ were determined by AAS, as in the analysis of the macroalga.

Sediment The collected sediments were dried in ambient conditions for a week followed by drying in an oven at $110{ }^{\circ} \mathrm{C}$ for 24 hours until a constant weight was attained. Dried samples (4 $\mathrm{g}$ each) were digested in concentrated nitric acid with heating on a hot plate to completely remove organic substances. The extract containing heavy metals was passed through the membrane filter, and the filtered extract was diluted with deionized water. The concentrations of $\mathrm{Fe} \mathrm{Pb}$, $\mathrm{Cu}, \mathrm{Zn}$ and $\mathrm{Cd}$ were also determined by the AAS.

\section{RESULTS AND DISCUSSION}

Heavy metal content in Ulva sp. The heavy metal content in Ulva sp. harvested in the Yatsu tidal flat is shown in Table 1. Based on the average concentrations, the heavy metals in Ulva sp. in decreasing order of concentration were $\mathrm{Fe} \gg \mathrm{Zn}>\mathrm{Pb} \geq \mathrm{Cu} \gg \mathrm{Cd}$ in July, and $\mathrm{Fe} \gg \mathrm{Zn}>\mathrm{Cu}>\mathrm{Pb} \gg \mathrm{Cd}$ in October. It is generally known that there are seasonal variations in heavy metal bioaccumulation in the macroalgae; the extent of bioaccumulation was less remarkable in the maximum growing period of summer than in the growth period of fall or winter ${ }^{6}$. This seasonal variation of the uptake of heavy metals into macroalgae is linked with metabolic processe ${ }^{7}$. A similar result was observed for Ulva sp. in the Yatsu tidal flat as relatively lower concentrations of heavy metals were observed in July than in October for some heavy metals. The concentrations of $\mathrm{Fe}, \mathrm{Cu}$ and $\mathrm{Zn}$ of Ulva sp. in October were more than 2 times the levels observed in July. On the contrary, seasonal variations could not be observed for $\mathrm{Pb}$ or $\mathrm{Cd}$, even though a small decline was observed for $\mathrm{Pb}$.

The results indicated that the extent of bioaccumulation of $\mathrm{Fe}, \mathrm{Cu}$ and $\mathrm{Zn}$ in Ulva sp. followed the general understanding of seasonal variations in organisms but those of $\mathrm{Pb}$ and $\mathrm{Cd}$ did not.

Heavy metal content of Ulva sp. found in the literature ${ }^{4,8-11)}$ are presented in Table 2.

Some differences in the heavy metal concentrations were present; $\mathrm{Pb}$ was lower in Ulva sp. from Greece and Turkey and Cd was lower in Ulva sp. of Turkey. The average values for $U$. rigida in Table 2 were calculated in which $\mathrm{Fe}$ concentration were tabulated and $\mathrm{Pb}$ concentrations of more than $1.0 \mu \mathrm{g} / \mathrm{g}$ dry wt. Based on average literature concentrations, heavy metals were found in decreasing order of $\mathrm{Fe}>\mathrm{Zn}>\mathrm{Cu}$. $\mathrm{Pb}>\mathrm{Cd}$. The rank of heavy metal concentrations of Ulva spp. were the same between Yatsu tidal flat and the data in the literature without some exception despite differences in growing season and region. The $\mathrm{Fe}$ and $\mathrm{Pb}$ content of Ulva sp. in Yatsu tidal flat were about 10 and 3 times as much, respectively, as the average value published in the literature. Very low content levels of Fe were reported in the data at Thermaikos Gulf ${ }^{4)}$ (Greece) and Black Sea ${ }^{9}$ (Turkey). Both study area, Thermaikos and Black Sea, are effected by inflow loads of domestic and industrial wastewater from drainage basin area ${ }^{4,8,9)}$ as same as Tokyo Bay. Both of Gulf and Sea are always sunk down under seawater surface, while Yatsu 
tidal flat is suffered from dryness at ebb tide. Therefore, Ulva spp. blooming in both Thermaikos and Black Sea cannot contact atmosphere directly. In Tokyo Bay area, the metal content, especially $\mathrm{Fe}$, in descent particulates are observed high levels as a result in steel industrial activity. $\mathrm{Fe}$ in descent particulates at neighborhood of Yatsu tidal flat were monitored/reported as 1068 $\mathrm{kg} / \mathrm{km}^{2} /$ year at $1998,852 \mathrm{~kg} / \mathrm{km}^{2} /$ year at 1999 , $636 \mathrm{~kg} / \mathrm{km}^{2} /$ year at $2000,924 \mathrm{~kg} / \mathrm{km}^{2} /$ year at 2001 and $948 \mathrm{~kg} / \mathrm{km}^{2} /$ year at $2002^{12)}$, while at Mediterranean Sea bordered Greece and Italy were estimated $32-140 \mathrm{~kg} / \mathrm{km}^{2} / \mathrm{year}^{13)}$ and $5-27 \mathrm{~kg} / \mathrm{km}^{2} /$ year $^{14)}$. There are possible that those descent particulates stick on the surface of Ulva sp., and act as the content rising of $\mathrm{Fe}$ and other metals. Ulva sp.

Table 1 Heavy metals in Ulva sp. grown in Yatsu tidal flat

\begin{tabular}{cccccc} 
& & & \multicolumn{3}{r}{$\mu \mathrm{g} / \mathrm{g}$ dry wt. } \\
\hline St. No. & $\mathrm{Fe}$ & $\mathrm{Pb}$ & $\mathrm{Cu}$ & $\mathrm{Zn}$ & $\mathrm{Cd}$ \\
\hline 1 & 8160 & 22.7 & 18.2 & 31.6 & 0.460 \\
2 & 8350 & 21.0 & 18.9 & 32.7 & 0.452 \\
3 & 7280 & 18.9 & 17.1 & 31.7 & 0.456 \\
July Ave. & 7930 & 20.9 & 18.1 & 32.0 & 0.456 \\
(Composition (\%)) & $(99.1)$ & $(0.261)$ & $(0.226)$ & $(0.400)$ & $(0.00570)$ \\
\hline 1 & 12000 & 15.4 & 29.5 & 78.8 & 0.489 \\
1 & 13400 & 19.0 & 33.4 & 87.0 & 0.565 \\
2 & 14300 & 18.7 & 45.1 & 102 & 0.483 \\
3 & 23000 & 22.2 & 45.5 & 105 & 0.614 \\
October Ave. & 15600 & 18.8 & 38.4 & 93.2 & 0.538 \\
(Composition (\%)) & $(99.0)$ & $(0.119)$ & $(0.244)$ & $(0.592)$ & $(0.00342)$ \\
\hline
\end{tabular}

corrected from Venice lagoon (Italy) where is drained at ebb tide ${ }^{11,15)}$ as same as Yatsu tidal flat shows higher content than both Thermaikos and Black Sea in Fe and other heavy metals. It is therefore considered that the trend of heavy metals in Ulva spp. at drained tidal zone is increased. Fe was the major component of Ulva sp. in Yatsu tidal flat $(99 \%)$ and for Ulva spp. in the literature (95\%). The $\mathrm{Zn}, \mathrm{Cu}, \mathrm{Pb}$ and $\mathrm{Cd}$ concentrations were one or two orders of magnitude lower than $\mathrm{Fe}$ for both in the experiments and in the literature. The heavy metal composition of other species of seaweed differed from Ulva spp.; for instance, the composition of Grateloupia in the order Florideophyceae was $52.9 \% \mathrm{Fe}, 0.538 \% \mathrm{~Pb}, 1.97 \% \mathrm{Cu}, 44.5 \% \mathrm{Zn}$, and $0.0359 \% \mathrm{Cd}^{11)}$ and that of Ascophyllum nodosum in the order Phaeophyceae was $80.9 \% \mathrm{Fe}, 0.0757 \% \mathrm{~Pb}, 1.99 \% \mathrm{Cu}, 16.8 \% \mathrm{Zn}$, and $0.218 \% \mathrm{Cd}^{10)}$. Though the composition of heavy metals for Grateloupia and for Ascophyllum is also similar to that of Ulva spp., the relative composition differed from Ulva spp. The Fe composition was $50-80 \%$ for Grateloupia and Ascophyllum while it was more than $95 \%$ for Ulva spp. The $\mathrm{Zn}$ composition in Grateloupia and Ascophyllum was $17-45 \%$ and was higher than that of Ulva spp. (less than 4\%). The heavy metal ratios in Ulva spp., therefore, were similar within Ulva spp., but were distinct from the other seaweeds.

Table 2 Reference data of heavy metals in Ulva spp.

\begin{tabular}{|c|c|c|c|c|c|c|c|}
\hline Species & Geographic area/season & $\mathrm{Fe}$ & $\mathrm{Pb}$ & $\mathrm{Cu}$ & $\mathrm{Zn}$ & $\mathrm{Cd}$ & Reference \\
\hline U. lactuca & Thermaikos, N.Krini (Greece) & - & 0.02 & 7.40 & 43.70 & 0.42 & 8 \\
\hline U. lactuca & Thermaikos, Kalochori (Greece) & - & 0.02 & 11.10 & 88.00 & 0.76 & 8 \\
\hline U. lactuca & Pagastikos, Pefka (Greece) & - & 2.80 & 8.30 & 49.30 & 0.24 & 8 \\
\hline U. lactuca & Pagastikos, Lehonia (Greece) & - & 0.02 & 9.00 & 79.90 & 0.54 & 8 \\
\hline U. lactuca & Crete, Heraklion (Greece) & - & 0.02 & 7.00 & 16.40 & 0.42 & 8 \\
\hline U. lactuca & Crete, Chania (Greece) & - & 0.02 & 14.50 & 56.30 & 1.10 & 8 \\
\hline U. lactuca & Black Sea (Turkey)/autumn & 778 & $<0.1$ & 13.80 & 21.20 & $<0.02$ & 9 \\
\hline U. lactuca & Black Sea (Turkey)/autumn & 550 & $<0.1$ & 3.87 & 9.60 & $<0.02$ & 9 \\
\hline U. rigida & Black Sea (Turkey)/autumn & 235 & 1.30 & 2.53 & 3.90 & 0.10 & 9 \\
\hline U. lactuca & St. LawrenceRiver (Canada)/summer & 2486 & 1.64 & 19.20 & 33.3 & 0.22 & 10 \\
\hline U. rigida & Thermaikos (Greece)/all year & 97.20 & 14.70 & 2.20 & 57.30 & 1.00 & 4 \\
\hline \multirow[t]{2}{*}{$U$. rigida } & Venice Lagoon (Italy)/spring and autum & 1033 & 7.30 & 13.00 & 64.00 & 0.20 & 11 \\
\hline & Ave. & 962.8 & 6.235 & 9.23 & 39.63 & 0.38 & \\
\hline
\end{tabular}




\section{Heavy metals concentrations in seawater}

Concentrations of heavy metals in seawater of the Yatsu tidal flat are shown in Table 3. The metals in decreasing order of concentration were $\mathrm{Fe} \gg \mathrm{Zn}>\mathrm{Cu} . \mathrm{Pb} \gg \mathrm{Cd}$ for both unfiltered and filtered seawater. The $\mathrm{Fe}$ content was decreased by more than $95 \%$ while that of $\mathrm{Pb}, \mathrm{Cu}, \mathrm{Zn}$ or $\mathrm{Cd}$ was decreased only by $5-10 \%$ by passing through the filter. The composition of $\mathrm{Fe}$ also decreased from $95.2 \%$ of the metals for unfiltered seawater to $58.2 \%$ for the filtered seawater. Fe concentration at Yatsu tidal flat was Higher levels than the concentrations at Tokyo Bay measured by Akagi and Haraguchi (1984). In general, at the shallow sea area such as tidal flat and/or coastal zone, the sediment is remarkably resuspended by sea waves and tidal current compared with relatively deepsea area. Therefore, it is considered that Fe and other metals concentrations are increased result in resuspension of sediment into seawater. However, the concentrations of the other measured heavy metals, $\mathrm{Pb}, \mathrm{Cu}$, $\mathrm{Zn}$ and $\mathrm{Cd}$, were similar levels to Tokyo Bay reported by Akagi and Haraguchi (1984) and Hirao et al. (1983). Consequently, it is able to gather that the sediment in Yatsu tidal flat compose much Fe compared with other heavy metals. The concentrations of $\mathrm{Pb}$ and $\mathrm{Cd}$ were lower levels than ambient environmental quality standard in Japan $(\mathrm{Pb}:<$ $0.01 \mathrm{mg} / l, \mathrm{Cd}:<0.01 \mathrm{mg} / l$ ). Moreover, concentrations of $\mathrm{Zn}$, which was added as "the environmental standard for preservation of aquatic creatures" at 2003 , were generally lower level compared with the standard $(<$ $0.01 \mathrm{mg} / l$ ). It is accordingly considered that the heavy metal pollutions in Yatsu tidal flat are lower levels.

The insoluble heavy metal content, most of which would be contained in the suspended particulate matter (SPM) fraction of seawater, were calculated by subtracting the metal content in filtered seawater from that in unfiltered seawater as expressed in concentration in the seawater in Table 3 . The insoluble heavy metal content was 370 $\mu \mathrm{g} / l$ for $\mathrm{Fe}, 2.4$ for $\mathrm{Pb}, 0.57$ for $\mathrm{Cu}, 6.2$ for $\mathrm{Zn}$ and 0.016 for $\mathrm{Cd}$. By relative composition, the samples were $97.6 \% \mathrm{Fe}, 0.641 \% \mathrm{~Pb}$, $0.151 \% \mathrm{Cu}, 1.64 \% \mathrm{Zn}$ and $0.00414 \% \mathrm{Cd}$ as shown in Fig.2. Based on these results, $\mathrm{Fe}$ was found to be the major component in SPM compared to the other heavy metals of $\mathrm{Pb}$, $\mathrm{Cu}, \mathrm{Zn}$ and $\mathrm{Cd}$.

Table 3 Heavy metals in seawater

\begin{tabular}{|c|c|c|c|c|c|c|}
\hline & & $\mathrm{Fe}$ & $\mathrm{Pb}$ & $\mathrm{Cu}$ & $\mathrm{Zn}$ & $\mathrm{Cd}$ \\
\hline \multirow{8}{*}{ Unfiltered } & March & - & 6.7 & 3.4 & 28 & - \\
\hline & April & - & 3.2 & 1.4 & 5.2 & 0.093 \\
\hline & April & - & 4.5 & 1.5 & 6.8 & 0.069 \\
\hline & April & - & 8.7 & 1.9 & 7.1 & 0.093 \\
\hline & May & 380 & 5.1 & 2.7 & 8.6 & 0.12 \\
\hline & May & 380 & - & - & - & - \\
\hline & May & 390 & - & - & - & - \\
\hline & $\begin{array}{c}\text { Ave. } \\
\text { (Composition (\%)) }\end{array}$ & $\begin{array}{c}380 \\
(95.2) \\
\end{array}$ & $\begin{array}{c}5.6 \\
(1.40) \\
\end{array}$ & $\begin{array}{c}2.2 \\
(0.542) \\
\end{array}$ & $\begin{array}{c}11 \\
(2.79) \\
\end{array}$ & $\begin{array}{c}0.094 \\
(0.0232) \\
\end{array}$ \\
\hline \multirow{9}{*}{ Filtered } & March & - & 2.2 & 1.9 & 5.0 & 0.23 \\
\hline & April & - & 3.2 & 0.37 & 3.0 & 0.046 \\
\hline & April & - & 4.0 & 1.9 & 6.0 & 0.044 \\
\hline & April & - & 3.0 & 2.4 & 6.8 & 0.015 \\
\hline & April & - & 0.21 & 1.2 & 3.6 & 0.015 \\
\hline & May & 17 & 6.6 & 1.8 & 5.9 & 0.11 \\
\hline & May & 11 & - & - & - & - \\
\hline & Ave. & 14 & 3.2 & 1.6 & 5.0 & 0.078 \\
\hline & (Composition (\%)) & $(58.2)$ & $(13.5)$ & $(6.78)$ & $(21.2)$ & $(0.328)$ \\
\hline \multirow{2}{*}{ SPM } & Ave. & 370 & 2.4 & 0.57 & 6.2 & 0.016 \\
\hline & (Composition (\%)) & $(97.6)$ & $(0.641)$ & $(0.151)$ & $(1.64)$ & $(0.00414)$ \\
\hline
\end{tabular}




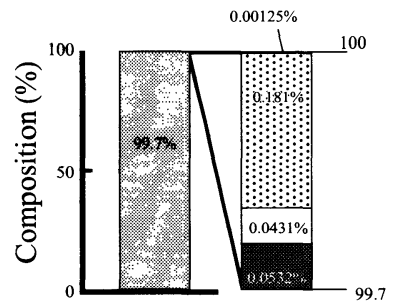

St. $1 \sim 3$

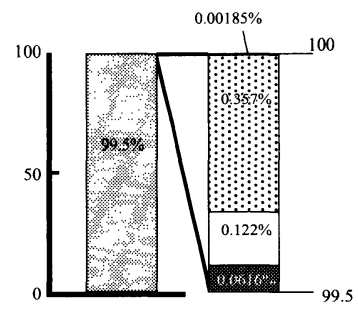

St.4, 5

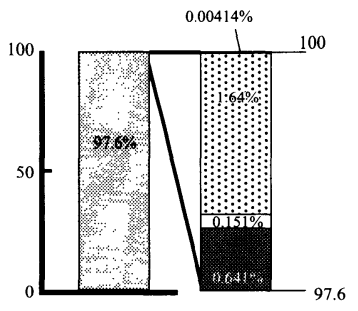

ISHM

$\square \mathrm{Fe} \quad \mathrm{Pb} \square \mathrm{Cu} \quad \mathrm{Zn} \square \mathrm{Cd}$

Fig. 2 Heavy metal composition in the sediment and insoluble heavy metals (ISHM) in seawater

\section{Heavy metal content in sediment}

Sediment heavy metal content in October in the Yatsu tidal flat are shown in Table 4. The metals in decreasing order of concentration were $\mathrm{Fe} \gg \mathrm{Zn}>\mathrm{Cu} . \mathrm{Pb} \gg \mathrm{Cd}$ for both areas; sand and mud areas. It is generally recognized that heavy metals are bound more in the fraction due to high surface area and the presence of organic complex ${ }^{18-22)}$. It is also widely shown that heavy metals are adsorbed to specific surface functional groups as carboxyl, carbonyl, hydroxyl and amino groups $^{23,24)}$. Yu reported that the heavy metal concentrations decreased with increasing sand composition in the surface of the sediment ${ }^{25)}$. As shown in Table 4, similar results were obtained in the Yatsu tidal flat; heavy metal content was higher in the muddy area of Sts. 4 and 5 than in the sandy area of Sts. 1 through 3 . The levels of ignition loss (IL) at sandy sediment area were lower than the levels at muddy sediment area in Yatsu tidal flat as shown in Table 5. in which IL is one of indicators for
Table 5 Ignition Loss (IL) in sediments corrected form both sandy and muddy area

\begin{tabular}{cccccc}
\hline \multirow{2}{*}{ Sampling points } & \multicolumn{3}{c}{ Sediment condition } \\
\cline { 2 - 3 } \cline { 5 - 6 } & \multicolumn{2}{c}{ sandy } & & \multicolumn{2}{c}{ muddy } \\
\cline { 2 - 3 } \cline { 5 - 6 } $\begin{array}{c}\text { Ignition Loss } \\
(\%)\end{array}$ & St.1 & St.3 & & St.4 & St.5 \\
\hline
\end{tabular}

organic matter composed in sediment; particles in the muddy area contain much amount of organic matter compared to in the sandy area. It is well known the organic matter, i.e. humic acids, provides surface functional groups for metal adsorption from the aqueous system ${ }^{26}$. Difference in heavy metals content between the muddy and sandy areas is supposed to be due to difference in content of organic matter. On the other hand, Lian and Wong recently (2003) concluded that the heavy metals can be retained in sediment not only by surface adsorption but also by precipitation ${ }^{27)}$. In Yatsu tidal flat, seawater is flown from Tokyo

Table 4 Heavy metals in sediments

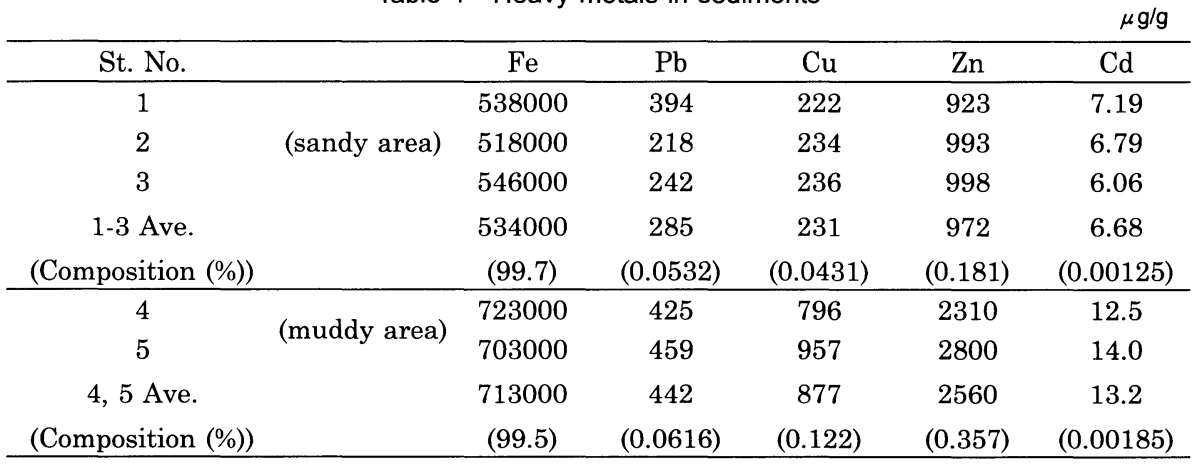


Bay at high tide and flown out to the bay at ebb tide with tidal cycle of the Bay by the two channels. It is able to be considered that water quality, e.g. salinity, $\mathrm{pH}, \mathrm{SPM}$ concentration, in the tidal flat is similar characteristics at either sandy or muddy area. Accordingly, it should be ignored the third retained factor i.e. precipitation, because seawater in the tidal flat is similar quality in all part of Yatsu tidal flat. Influence of organic sedimentation derived from Ulva sp. was infinitesimal by the reason of low IL levels on sandy area covered with Ulva sp.. In addition, the influence of Ulva sp. on the content of heavy metals in sediment was also negligible as shown in Table 4, i.e. the amount of heavy metals in Ulva sp. is much smaller than the difference in concentration of the heavy metals in the sediments.

The heavy metal compositions of the sediments are depicted in Fig.2 and are compared to the insoluble heavy metal (ISHM) composition in seawater. The heavy metal compositions of $\mathrm{Zn}, \mathrm{Cu}, \mathrm{Pb}$ and $\mathrm{Cd}$, excluding $\mathrm{Fe}$, are also depicted in Fig.2. When the insoluble heavy metal composition was assumed to be identical with that of SPM, the composition of SPM was similar to that of the sediments, not only for $\mathrm{Fe}$ as an abundant heavy metal, but also for the other four elements of $\mathrm{Zn}, \mathrm{Cu}, \mathrm{Pb}$ and $\mathrm{Cd}$. Considering the fact that there is no material supply from the land area of Yatsu tidal flat, the SPM observed in the seawater would be coming from the sediment released in the tidal flat by tidal shear force.

Bioaccumulation of Heavy Metals In general, it was well recognized that bioabsorption of heavy metals into algae occurs by direct metal absorption from seawater ${ }^{28,29)}$. Concentration Factor (CF) defined by Eq.(1) was employed to represent bio-absorption of heavy metals by Ulva sp. from seawater.

$$
C F=\frac{C_{U l v a}}{C_{s w}}
$$

where $C_{U l v a}$ and $C_{s w}$ are the heavy metal concentrations in Ulva sp. $(\mu \mathrm{g} / \mathrm{g})$ and in the filtered seawater $(\mathrm{mg} / l)$, respectively. The average values calculated for July and
October samplings of all stations were used for $C_{U l v a}$ and $C_{s w}$. The resulting CFs were 575000 for $\mathrm{Fe}, 6510$ for $\mathrm{Pb}, 11200$ for $\mathrm{Cu}$, 6350 for $\mathrm{Zn}$ and 5850 for Cd in July, and 1130000 for $\mathrm{Fe}, 5860$ for $\mathrm{Pb}, 23900$ for $\mathrm{Cu}$, 18500 for $\mathrm{Zn}$ and 6910 for $\mathrm{Cd}$ in October as shown in Fig. 3. There were no major differences in $\mathrm{CF}$ ratios for $\mathrm{Pb}, \mathrm{Zn}$ and $\mathrm{Cd}$ in July, which is the maximum growing season of Ulva sp. The content of $\mathrm{Fe}, \mathrm{Cu}$ or $\mathrm{Zn}$ in October was two or three times higher than that in July. Assuming that the absorbability of each heavy metal species to Ulva sp. was similar, the heavy metal content in Ulva sp. must be proportional to the heavy metal concentration in seawater. Although the $\mathrm{Fe}$ concentration of filtered seawater was only a little greater than that of $\mathrm{Pb}, \mathrm{Cu}, \mathrm{Zn}$ and $\mathrm{Cd}$, the $\mathrm{CF}$ of $\mathrm{Fe}$ was extraordinarily higher than any other metal found in Ulva sp., as shown in Fig. 3, indicating that Ulva sp. absorbed $\mathrm{Fe}$ with particularly high selectivity in its growing process. The $\mathrm{CF}$ of $\mathrm{Cu}$ for Ulva sp. was higher than that of $\mathrm{Pb}$ or $\mathrm{Zn}$ both in July and October despite the $\mathrm{Cu}$ concentration in filtered seawater being less than $\mathrm{Pb}$ or $\mathrm{Zn}$. The $\mathrm{CF}$ of $\mathrm{Cd}$ was close to that of $\mathrm{Pb}$ or $\mathrm{Zn}$ in July, though the Cd concentration was more than one order of magnitude lower than that of $\mathrm{Pb}$ or $\mathrm{Zn}$. The results indicated that $\mathrm{Cd}$ was also selectively absorbed to Ulva sp. The difference in absorption capacities of heavy metals, therefore, depends on the difference in elemental absorbabilities rather than the differences in concentration.

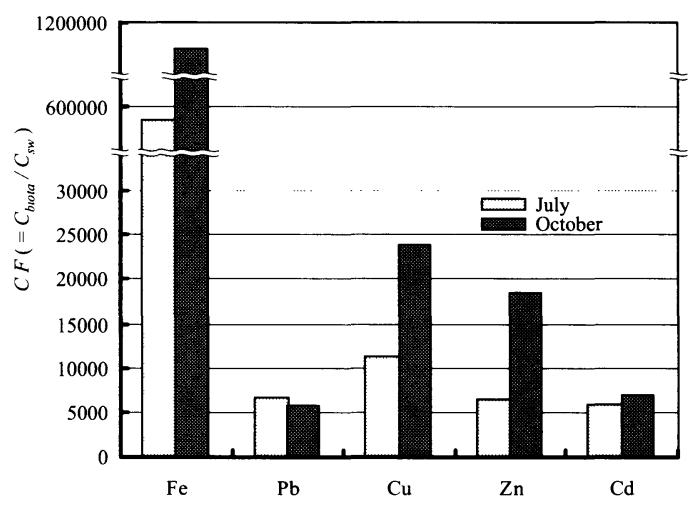

Fig. 3 Concentration factors of heavy metals for Ulva sp. 
From another point of view, $\mathrm{Fe}, \mathrm{Cu}$ and $\mathrm{Zn}$ are essential elements for the growth of algae, while $\mathrm{Pb}$ and $\mathrm{Cd}$ are toxic elements without any biological function ${ }^{30}$. Based on the $\mathrm{CFs}$ observed in October, $\mathrm{Fe}, \mathrm{Cu}$ and $\mathrm{Zn}$ were relatively easily absorbed compared to $\mathrm{Pb}$ and $\mathrm{Cd}$. Consequently, it was considered that Ulva sp. would efficiently absorb essential elements for the formation of cells.

The increases in $\mathrm{CFs}$ for $\mathrm{Pb}$ and $\mathrm{Cd}$ were limited from July to October, while the increase in CFs were observed for $\mathrm{Fe}, \mathrm{Cu}$ and $\mathrm{Zn}$. Comparing the $\mathrm{CFs}$ of $\mathrm{Cu}$ with $\mathrm{Zn}$, the increase in $\mathrm{Zn}$ from July to October was more pronounced than that of $\mathrm{Cu}$. $\mathrm{Cu}$ is known to be a toxic element in a large numbers of organisms but is essential in suitable amounts. In general, marine algae has the capability to eliminate the influence of $\mathrm{Cu}$ when it exists in excess amounts in the cell, by methods such as exclusion out of the cell, decrease in absorption ability, detoxification in cell or conversion to non-toxic stable compounds. Most macroalgae generate an organic ligand that can form the complex with $\mathrm{Cu}$ ions outside the cell to control the $\mathrm{Cu}$ concentration inside the cell ${ }^{311}$. The smaller increase in $\mathrm{CF}$ of $\mathrm{Cu}$ than $\mathrm{Zn}$ from July to October could be attributed to the capability of controlling $\mathrm{Cu}$ concentration in Ulva sp.

\section{CONCLUSIONS}

By examining the heavy metal concentrations of Ulva sp., the seawater and the sediments in Yatsu tidal flat and their relationships, the following conclusions were deduced.

1. In Ulva sp., the heavy metal concentrations of $\mathrm{Fe}, \mathrm{Cu}$ and $\mathrm{Zn}$ increased from July to October, but remained unchanged for $\mathrm{Pb}$ and $\mathrm{Cd}$. Hence, the increases in $\mathrm{Fe}$, $\mathrm{Cu}$ and $\mathrm{Zn}$ contents of Ulva sp. obeyed general seasonal variations, though $\mathrm{Pb}$ and $\mathrm{Cd}$ contents did not show seasonal variations.

2. Comparing the heavy metal concentrations of Ulva spp. in Yatsu tidal flat with those of other regions, a similar metal composition was obtained within the species, despite differences in season and region, but differences arose in other species. Therefore, Ulva spp. were considered to have an inherent heavy metal composition.

3. The heavy metal concentrations of sediments in the Yatsu tidal flat were higher in the muddy area than in the sandy area. Difference in heavy metals concentration between the muddy and sandy areas is proposed to be caused by difference in concentration of organic matter. The influence of Ulva sp. on the heavy metals content in the sediments could be negligible because the content of heavy metals in the sandy area were much smaller than those in the muddy area.

4. When the insoluble heavy metal composition was assumed to be identical with that of SPM, the composition in the SPM was similar to that of the sediments, not only for $\mathrm{Fe}$ as a major heavy metal component, but for the other minor elements of $\mathrm{Zn}, \mathrm{Cu}, \mathrm{Pb}$ and $\mathrm{Cd}$. The SPM in Yatsu tidal flat seawater would be come from the stirred up sediment because no material was supplied from the land area.

5. Considering CFs of heavy metals in Ulva sp., the difference in absorption capacities of heavy metals would depend on the differences in elemental absorbabilities, rather than the differences in heavy metal concentrations in seawater; Ulva sp. efficiently absorbs essential elements of $\mathrm{Fe}, \mathrm{Cu}$ or $\mathrm{Zn}$ for the formation of cells and selectively absorbs the toxic elements that lack biological function, such as $\mathrm{Pb}$ and $\mathrm{Cd}$.

\section{REFERENCES}

1 ) Brown MT., Hodgkinson WM. and Hurd CL.: Spatial and Temporal Variations in The Copper and Zinc Concentrations of Two Green Seaweeds from Otago Harbour, New Zealand, Marine Environmental Research, 47, 175-184 (1999)

2) Lee WY. and Wang WX.: Metal Accumulation in The Green Macroalga Ulva fasciata: Effects of Nitrate, Ammonium and Phosphate, The Science of the Total Environment, 278, 11-22 (2001)

3 ) Muse JO., Strepeikis JD., Fernández FM., 
d'Huicque L., Tudino MB., Carducci CN. and Troccoli OE.: Seaweeds in The Assessment of Heavy Metal Pollution in The Gulf San Jorge, Argentina, Environmental Pollution, 104, 315-322 (1999)

4 ) Haritonidis S. and Malea P.: Bioaccumulation of Metals by The Green Alga Ulva rigida from Thermaikos Gulf, Greece, Environmental Pollution, 104, 365-372 (1999)

5 ) Ishii Y., Murakami K. and Taki K.: Succession of Yatsu Tidal Flat Concerned with Main Environmental Factors, Papers on Environmental Information Science, 14, 213-218 (2000)

6 ) Villares R., Puente X. and Carballeira A.: Seasonal Variation and Background Levels of Heavy Metals in Two Green Seaweeds, Environmental Pollution, 119, 79-90 (2002)

7 ) Eide I., Myklestad S. and Melsom S.: LongTerm Uptake and Release of Heavy Metals by Ascophyllum nudosum (L.) LeJol. (Phaeophyceae) in situ, Environmental Pollution, 23, 19-28 (1980)

8 ) Sawidis T., Brown MT., Zachariadis G. and Sratis I.: Trace Metal Concentrations in Marine Macroalgae from Different Biotopes in The Aegean Sea, Environment International, 27, 43-47 (2001)

9 ) Topcuo. lu S., Güven K. C., Balkis N. and Kirba. O lu .: Heavy Metal Monitoring of Marine Algae from The Turkish Coast of The Black Sea, 1998-2000, Chemosphere, 52, 1683-1688 (2003)

10) Phaneuf D., Cote I., Dumas P., Ferron LA. and LeBlanc A.: Evaluation of The Contamination of Marine Algae (Seaweed) from The St. Lawrence River and Likely to Be Consumed by Humans, Environmental Research Section A, 80, S175-S182 (1999)

11) Caliceti M., Argese E., Sfriso A. and Pavoni B.: Heavy Metal Contamination in The Seaweeds of The Venice Lagoon, Chemosphere, 47, 443-454 (2002)

12) Atmospheric Division, Chiba pref.: Annual Report of Atmospheric Environmental Research in Chiba Prefecture, p144 (2003)

13) Guieu C., Chester M., Nimmo M., Martin
J.M., Guerzoni S., Nicolas E., Mateu J. and Keyse S.: Atmospheric Input of Dissolved and Particulate Metals to The Northwestern Mediterranean, Deep-Sea Research II, 44, 655-674 (1997)

14) Poulichet F. E., Guieu C. and Morley N. H.: A reassessment of Trace Metal Budgets in The Western Mediterranean Sea, Marine Pollution Bulletin, 42, 623-627 (2001)

15) Casabianca M. L., Barthelemy N. Serrano O. and Sfriso A.: Growth Rate of Ulva rigida Different Mediterranean Eutrophicated Sites, Bioresource Technology, 82, 27-31 (2002)

16) Akagi T. and Haraguchi H.: Distribution and Behaviors of Trace Heavy Metals in The Tama River Estuary and Tokyo Bay, Geochemistry, 18, 81-88 (1984)

17) Hirao Y., Koshikawa M., Sugisaki H., Fukumoto K., Kimura K. and Matsumoto E.: Lead, Copper and Cadmium Concentration in The Seawater of Tokyo Bay, Geochemistry, 17, 42-47 (1983)

18) Klamer H. J. C, Hegeman W. J. M amd Smedes F.: Comparison of Grain Size Correlation Procedures from Organic Micropollutants and Heavy Metal in Marine Sediments, Hydrobiology, 208, 123-220 (1990)

19) Tam N. F. Y and Wong Y. S.: Retention and Distribution of Heavy Metal in Mangrove Soils Reciving Wastwater, Environmental Pollution, 94, 283-291 (1995)

20) Vertacnik A., Prohic E., Kozar S. and Juracic M.: Behaviour of Some Trace Elements in Alluvial Sediments, Zagerb Water-Well Field Area, Croatoa, Water Research, 29, 237-246 (1995)

21） Balls P. W., Hull S., Miller B. S., Pirie J. M. and Proctor W.: Trace Metal in Scottish Estuarine and Coastal Sediments, Marine Pollution Bulletin, 34, 42-50 (1997)

22) Reddy M. S., Basha S., Kumar V. G. S., Joshi H. V. and Ramachandraiah G.: Distribution, Enrichment and Accumulation of Heavy Metals in Coastal Sediments of Alang-Sosiya Ship Scrapping Yard, India, Marine Pollution Bulletin, 48, 1055-1059 (2004) 
23) Jal P. K., Patel S. and Mishra B. K.: Chemical Modification of Silica Surface by Immobilization of Functional Groups for Extractive Concentration of Metal Ions, Talanta, 62, 1005-1028 (2004)

24) Pesavento M., Profumo A., Alberti G. and Conti F.: Adsorption of Lead(II) and Copper(II) on Activated Carbon by Complexation with Surface Functional Groups, Analytical Chimica Acta, 480, 171-180 (2003)

25) Yu S.: Distribution and Behavior of Heavy Metals in Surface Sediment from Estuaries and Inner Part of Tokyo Bay, Water purification and liquid wastes treatment, 27, 843-849 (1986)

26) Ashley T. F. J.: Adsorption of $\mathrm{Cu}(\mathrm{II})$ and $\mathrm{Zn}$ (II) by Estuarine, Riverine and Terrestrial Humic Acids, Chemosphere, 33, 2175-2187 (1996)

27) Lian Y. and Wong M. H.: Spatial and
Temporal Organic and Heavy Metal Pollution at Mai Po Marshes Nature Reserve, Hong Kong, Chemosphere, 52, 1647-1658 (2003)

28) Sunda WR. and Guillard RRL.: The Relationship Between Cupric Ion Activity and The Toxicity of Copper to Phytoplankton, Journal of Marine Research, 34, 511-529 (1976)

29) Anderson MA., Morel FM. and Guillard RRL.: Growth Limitation of A Coastal Diatom by Low Zinc Ion Activity, Nature, 276, 70-71 (1978)

30) Goldsmith E.: The Earth Report, Tokyo Shoseki press, 221-222, Tokyo (1990)

31) Notoya M.: Utlization of Ulva spp. and Environmental Restoration, Seizando press, 98-100, Tokyo (1999)

(Submitted 2004. 5. 24)

(Accepted 2004. 9. 1) 